\title{
The Education Existence During Sinabung Eruption Emergency Period
}

\author{
*Ermita Dahliana ${ }^{1)}$ and Marlon Sinaga ${ }^{2)}$
}

1) Graduate Student of Geography Education, Faculty of Social Science, Universitas Negeri Padang, Indonesia

2) SMA Santa Maria, Pekanbaru, Riau-Indonesia

Email: ermitadahliana123@yahoo.co.id

*Corresponding Author, Received: April 15, 2018, Revised: May 02, 2018, Accepted: May 20, 2018

This is an open acces article distributed under the Creative Commons 4.0 Attribution License, wich permits unrestricted use, Distribution, and reproduction in any medium provided the original work is properly cited @2017 by author and Universitas Negeri Padang

\begin{abstract}
This study aims to collect, process, analyze and describe the profile of education in emergency relief Sinabung Volcano eruption. This study is a descriptive study using qualitative data. Data were collected by using interview techniques, observation and documentation. This research perform about profile about education at SMA Negeri 1 Simpang Empat. Results illustrate that the profile of education in emergency relief in terms of the learning process should not be running optimally, educational facilities were damaged so it can not be used anymore, formal and informal education should be evacuated to a safer place.
\end{abstract}

Keywords: Education, Eruption, Emergency

\section{Introduction}

Indonesia archipelago is located among places named Indonesia. Australia plate, it caused by a pressure on underground layer/surface which made The Indonesian Archipelago district had a mountainous morphology. Besides, Indonesia archipelago also passed by active mountain in the world named Mediterania and Pacific, one of the active volcanos' that showed its exixtence recently is Sinabung Volcano. Sinabung Volcano in Karonese is called Karo Deleng located in Karo highland, Karo regency, North Sumatra, Indonesia. The climax coordinate of Sinabung Mountain is $0310 \mathrm{LU}$ and 5823 BT. Sinabung and Sibayak mountains are two active volcanos in North Sumatra and become the highest peak in North Sumatra province. The heigh of the mountain is approximately $2.460 \mathrm{~m}$ above the sea level (Fianet, 2014; Hermon, 2014; Hermon, 2017).

Based on Mr Budi's explanation from Geology Foundation that occupied in Sinabung Volcano Observation Center, the mountain never showed an explosion since 1600. Then finally Sinabung volcano be active on august 272010 and spread out the smoke and volcanic ash. The eruption existence change the mountain type, type B to type A in an emergency. There's no hints for the eruption increases previously so there's warning for that As brief explanation about the history of Sinabung Volcano which directly or indirectly will give the negative impact for the education. Education is a kind of process to change behavior and also the attitude of someone or a group of people related to improve the human being through the teaching, workshop, or the process, action and the way to educate (Daryanto, 1998). Education at school is a part of education that needed by all people in Indonesia. Because school can create intelligent human being through education (Suryohadiproyo, 2007) that explanation is as fit to command that exist in UUD 1945 about Indonesia right to get a good education and to improve the human living.

The learning process in education system should be held interactively, pleasantly, more challenging and also can motivate the students to be more enthusiastic, participate well and also give enough space for the creativity and be an independent student as fit to their talent, intention and the student's psychology. So, it is very crucial in education system for preparing such a good lesson plan, the learning process and also the 
assessment for the learning process to improve the effectiveness and efficiency related to the student's competency achievement.

However, it seems hard to gain such a good learning process in a district nearby Sinabung volcano. It is caused by the Sinabung volcano's eruption, there are so many schools destroyed. The eruption destroyed many things there, in fact some schools fall down because of the ash, oxidation from the eruption. In spite of the Sinabung volcano eruption, the learning process is still going on as usual as fit to the Culture and Education Minister's command, named M. Nuh in his latest visitation to Karo regency (on January 31 2014). He said that," all children must study eventhough they are in refugee place (Hermon, 2014)

\section{Method}

This research is a kind of descriptive research with qualitative data from primary and secondary data. This research was conducted on August 25 to August 26 2014. The data collection was conducted by the interview, observation and documentation. The data analysis process was conducted systematically.

\section{Results and Discussion}

The research findings stated that in emergency situation, the students as refugee of that disaster remained to study by inviting the teachers to the refugee places. The learning process was started at 13.30 p.m to 17.10 p.m with the time 30 minutes per meeting. Meanwhile it should be 40 minutes per meeting for the secondary school. It means that they missed 15 minutes per meeting and in a week they missed 640 minutes (15 lesson hour) for their learning process.

The learning process in the emergency situation caused by Sinabung volcano was held with a certain condition related to teachers, students, school existence and the facility provided. That condition caused the teachers could not do their duty as fit to the previous regulation, it seemed like to be just for how the learning process can go on. Eventhough it could not run well as usual, the teachers always tried to give their best for their students.

Eventhough the teachers could not give such a good lesson plan as fit to the government's expectation for the application of 2013 curriculum after the disaster. As the impact of the Sinabung eruption, the education facility in a destroyed district that existed about 3 to 5 kilometers from the Sinabung eruption could not be used as well, so that the learning process was moved to the safe place for an uncertain time because of the broken school. All the school facilities could not be use as well as usual in the learning process.

There are 8 broken school destroyed by the Sinabung eruption, and there's one school that it seemed to be the worst, named SMPN1 Naman Teran, while the other schools a little bit better and this caused the learning process should be moved to safe place or area. SMPN1 Naman Teran and SMAN 1 Simpang Empat moved to SMPN 2 Simpang Empat. SMPN1 Atap 2 Payung and SMPN 1 Simpang Empat moved to the refugee place and 4 schools had already back to their school. SMPN1 Naman Teran that got worst destroy got a help or support from Culture and education Ministry. It was planned to be repaired and for 6 months after the eruption, they studied in refugee places that given by the UNICEF. For the schools that got a little destroyment had been repaired, so there were 4 schools for that:

1. SMPN1 Naman Tigan Derket

2. SMAN1 Naman Tigan Derket

3. SMPN1 Payung

4. SMP Siempat Teran Naman

Related to the Sinabung volcano explosion, students from elementary grade to senior high school students, included formal and non-formal education institution had to move to the nearest school eventhough the students haven't been facilitated well yet, the learning process was still held in the refugee places. In emergency period, the learning process ever stopped, however remembering about the importance of education for Indonesia citizen, after the eruption the learning process was held as usual eventhough it couldnt be done as well. As the effect of Sinabung eruption, the education facilities that infected by the volcanic ash could not 
be used as well, so the teaching-learning process should be moved for uncertain period, because of the destroyed school. The education from elementary to the secondary level included formal and non-formal education institution also moved to the nearest school after getting the permission from the education department.

\section{Conclusion}

Based on the research finding above, so that the researcher gave suggestions as follow: First, the teacher as professional person was expected to be able as a motivator to encourage the students for having a good capability to resume their education. Second, school as a place for the learning process was expected to be able to encourage the teachers and the students as well as possible so that the learning process could run smoothly. Third, the government expected that for region and national, the formal and non-formal education institution could cooperate very well and helped the victim of the Sinabung volcano eruption in all aspects especially for the education could repair the broken facilities immediately.

\section{References}

Daryanto, S.S. (1998). Kamus Lengkap Bahasa Indonesia. Surabaya. Apollo.

Edi, R. (2014). Siswa Korban Sinabung Harus Tetap Belajar. Berita Sore 27 April 2018 (Online) (http://beritasore.com/2018/04/27/siswa-korban-sinabung-harus-tetap-belajar.html) diakses 27 April 2018.

Fianet. (2014). Sejarah Letusan Gunung Sinabung. Blogspot, April 2018 (Online). (http://fianetmu.com/2018/02/sejarah-letusan-gunung -sinabung-di-kabupaten-karo.html) diakses 27 April 2018

Hermon, D. (2014). Geografi Bencana Alam. Radjawali Press.

Hermon, D. (2017). Climate Change Mitigation. Rajawali Pers (Radjagrafindo). Jakarta.

Suryoadiprojo, S. (2007). Rakyat Sejahtera Negara Kuat. Jakarta. Pustaka Intermasa 